\title{
Excitation-Contraction Coupling in Heart
}

\author{
VII. CALCIUM ACCUMULATION IN SUBCELLULAR \\ PARTICLES IN CONGESTIVE HEART FAILURE
}

\author{
Prakash V. Sulakhe and Naranjan S. Dhalla \\ From the Department of Physiology, Faculty of Medicine, University of \\ Manitoba, Winnipeg 3, Canada
}

A B S T R A T The ability of heavy microsomes and mitochondria, isolated from the control and failing hearts of genetically dystrophic hamsters (BI0 14.6 strain), to accumulate calcium was examined. The rate and extent of energy-linked calcium binding (in the absence of oxalate) by the heavy microsomes of the failing heart were markedly depressed. The calcium uptake (in the presence of $5 \mathrm{~mm}$ oxalate) by the heavy microsomes of the failing heart was similar to that of the control heart. On the other hand, both the rate and extent of energylinked calcium binding (in the absence of $\mathrm{Pi}$ and succinate) and calcium uptake (in the presence of $4 \mathrm{~mm} \mathrm{Pi}$ and $5 \mathrm{~mm}$ succinate) by mitochondria were greatly reduced in the failing heart in comparison to the control. No difference in the total adenosine triphosphatase activities $\left(\mathrm{Ca}^{++}-\mathrm{Mg}^{++}\right.$stimulated) of heavy microsomes or mitochondria was observed between the control and failing hearts. These results indicate an abnormality of subcellular membranes of the failing heart to bind calcium and support the growing conviction concerning the defective "calcium pump" as a molecular abnormality associated with a moderate degree of congestive heart failure.

\section{INTRODUCTION}

The involvement of a defect in the excitation-contraction coupling mechanism $(1,2)$ in heart failure has been suspected by various investigators $(3-6)$. The current concept of excitation-contraction coupling implies that the release of calcium from a superficial membrane site in the cell in response to depolarizing impulse, results in myocardial contraction by activating the contractile apparatus. In the heart, sarcoplasmic reticulum mainly and mitochondria to some extent are considered to bring about relaxation due to their abilities to sequester cal-

Received for publication 3 September 1970 and in revised form 23 November 1970. cium from sarcoplasm by energy dependent mechnisms. Thus, the ability of subcellular structures to regulate intracellular calcium constitutes an important factor for determining the contractile state of myocardium.

Numerous investigators have attempted to show an abnormality of sarcotubular vesicles to accumulate calcium in heart failure induced by different procedures. For example, Gertz, Hess, Lain, and Briggs (7) have reported that the ability of heavy microsomes to accumulate calcium was markedly impaired in spontaneously failing dog heart-lung preparation. A decrease in both the rate and extent of calcium accumulation by the heavy microsomes of the ischemic dog heart muscle was also demonstrated (8). Harigaya and Schwartz (9) have shown a reduced rate of calcium binding by the heavy microsomes isolated from the failing human heart. The preliminary work of Suko, Vogel, and Chidsey (10) using heavy microsomes obtained from the right ventricle of calves with right ventricular failure due to chronic pulmonary hypertension also indicate a defect in calcium pump mechanism. Furthermore, a lesion in the energy-linked calcium transport acros the subcellular fractions was observed in the failing rat heart on perfusion with substrate-free medium $(11,12)$.

In the present report, we have investigated the calcium accumulating abilities of both cardiac mitochondria and heavy microsomes obtained from the genetically dystrophic hamsters (BI0 14.6 strain) with a moderate degree of congestive heart failure. While this study was in progress, two abstracts concerning the biochemical defect of heavy microsomes in the hereditary cardiomyopathy of the Syrian hamsters have been presented at a recent meeting $(13,14)$. It may be pointed out that a hamster (BI0 14.6 strain) which develops a hereditary cardiomyopathy terminating in failing heart has been regarded as a suitable disease model for studying molecular mechanisms involved in the pathogenesis of congestive heart failure (15-19). The work performance, tension develop- 
ment, contractility, and stress relaxation of the heart in these animals have been found to be markedly depressed $(20-22)$. The results described in this paper reveal a defect in calcium binding by cardiac mitochondria and heavy microsomes from genetically dystrophic hamsters and suggest that such an abnormality may be an important determinant of events leading to the impairment of myocardial function.

\section{METHODS}

Control and genetically dystrophic hamsters (BI0 14.6) were decapitated, hearts quickly removed, and subcellular fractions isolated according to the following procedures:

Procedure " $A$ " After thoroughly washing the heart with $0.25 \mathrm{M}$ sucrose containing $1 \mathrm{~mm}$ EDTA (ethylenediaminetetraacetate), $\mathrm{pH} 7.0$, the tissue was homogenized in 10 volumes of medium (10 $\mathrm{mm}$ sodium bicarbonate, $5 \mathrm{~mm}$ sodium azide, and $15 \mathrm{~mm}$ Tris(tris[hydroxymethyl] aminomethane) $-\mathrm{HCl}, \mathrm{pH}$ 6.8) in a Waring Blendor, Waring Products, New Hartford, Conn., for $45 \mathrm{sec}$. The homogenate was filtered through four layers of gauze and centrifuged at $10,000 \mathrm{~g}$ for $20 \mathrm{~min}$ to remove cell debris, nuclei, myofibrils, and mitochondria. The residue was discarded and the supernatant was spun at $40,000 \mathrm{~g}$ for $45 \mathrm{~min}$. The sediment thus obtained was washed thoroughly, suspended in $0.6 \mathrm{M} \mathrm{KCl}$ containing $20 \mathrm{mM}$ Tris- $\mathrm{HCl}, \mathrm{pH} 6.8$ and centrifuged at $40,000 \mathrm{~g}$ for $45 \mathrm{~min}$. This procedure was repeated twice and the final pellet (heavy microsomes or microsomal fraction) was suspended in $50 \mathrm{mM} \mathrm{KCl}, 20 \mathrm{mM}$ Tris-HCl, $\mathrm{pH} 6.8$ at a protein concentration of $3-5 \mathrm{mg} / \mathrm{ml}$. This method of isolation of the heavy microsomes is essentially similar to that described by Harigaya and Schwartz (9) in which azide was employed in the homogenizing medium. The addition of azide in this homogenizing medium yielded a very active preparation of cardiac heavy microsomes in terms of calcium pump with minimal contribution of mitochondrial fragments since azide is known to inactivate mitochondrial ATPase (adenosine triphosphatase).

Procedure " $B$ " For isolating mitochondria, the hearts were homogenized with 10 volumes of medium $(0.18 \mathrm{M}$ $\mathrm{KCl}, 10 \mathrm{~mm}$ EDTA, $0.5 \%$ albumin (fatty acid free), $\mathrm{pH}$ 7.4) in a Waring Blendor for $20 \mathrm{sec}$. The homogenate after filtering through two layers of gauze was spun at $1000 \mathrm{~g}$ for $20 \mathrm{~min}$ to remove cell debris, nuclei, and myofibrils. The supernatant was spun at $10,000 \mathrm{~g}$ for $20 \mathrm{~min}$. The sediment thus obtained was suspended in the homogenizing medium, centrifuged at $1000 \mathrm{~g}$ for $10 \mathrm{~min}$, and the residue discarded. The supernatant was further centrifuged at $8,000 \mathrm{~g}$ for $10 \mathrm{~min}$. This washing procedure was repeated twice and the final pellet (mitochondria) was suspended in 50 $\mathrm{mm} \mathrm{KCl,} 20 \mathrm{~mm}$ Tris- $\mathrm{HCl}, \mathrm{pH} 6.8$ at a protein concentration of $3-6 \mathrm{mg} / \mathrm{ml}$. This procedure for isolating the mitochondria is similar to that described by Sordahl and Schwartz (23).

Procedure " $C$ " By this method, both mitochondria and heavy microsomes were isolated from the same tissue. The heart was homogenized with 10 volumes of medium $(0.25 \mathrm{M}$ sucrose, $1 \mathrm{~mm}$ EDTA, $\mathrm{pH} 7$ ) in Waring Blendor for $40 \mathrm{sec}$. The homogenate was filtered through a gauze, centrifuged first at $1,000 \mathrm{~g}$ for $20 \mathrm{~min}$ and then at $10,000 \mathrm{~g}$ for $20 \mathrm{~min}$ to obtain mitochondrial sediment. This sediment was washed and suspended in the homogenizing medium, spun at $1,000 \mathrm{~g}$ for $10 \mathrm{~min}$, residue discarded and further centrifuged at $8,000 \mathrm{~g}$ for $10 \mathrm{~min}$ to obtain mitochondrial fraction. The post $10,000 \mathrm{~g}$ supernatant was centrifuged at $40,000 \mathrm{~g}$ for
$45 \mathrm{~min}$, the sediment washed, resuspended in $0.6 \mathrm{M} \mathrm{KCl}$, and centrifuged at $40,000 \mathrm{~g}$ for $45 \mathrm{~min}$ to separate heavy microsomes. Both mitochondrial and reticular fractions obtained by this method were suspended in $0.25 \mathrm{M}$ sucrose, $10 \mathrm{mM}$ Tris $\mathrm{HCl}, \mathrm{pH} 7.0$ at a protein concentration of $2-5 \mathrm{mg} / \mathrm{ml}$.

Procedure " $D$ " In experiments where liver was used, the tissue was cut into small pieces by a pair of scissors, washed thoroughly in medium containing $0.25 \mathrm{M}$ sucrose, $5 \mathrm{~mm}$ EDTA, $10 \mathrm{~mm}$ Tris- $\mathrm{HCl} \mathrm{pH} \mathrm{7.0,} \mathrm{and} \mathrm{homogenized} \mathrm{in} 10$ volumes of the same medium in a glass teflon homogenizer by hand (six to eight strokes). The homogenate, after filtering through two layers of gauze, was spun at $1000 \mathrm{~g}$ for $15 \mathrm{~min}$ and the supernatant centrifuged at $8,500 \mathrm{~g}$ for 15 min. The sediment thus obtained was suspended in homogenizing solution and again spun at $1000 \mathrm{~g}$ for $10 \mathrm{~min}$, the residue discarded, and the supernatant centrifuged at $8,500 \mathrm{~g}$ for $10 \mathrm{~min}$. This procedure was repeated twice and the mitochondrial fraction thus obtained was suspended in $0.25 \mathrm{mM}$ sucrose, $10 \mathrm{~mm}$ Tris- $\mathrm{HCl}, \mathrm{pH} 7.0$ at a protein concentration of $5-10 \mathrm{mg} / \mathrm{ml}$.

All the above procedures for isolating subcellular fractions were carried out at $0-4^{\circ} \mathrm{C}$. The protein concentration of these fractions was determined by Lowry's method (24). The glucose-6-phosphatase, $5^{\prime}$ nucleotidase, and cytochrome $c$ oxidase activities of these subcellular fractions were determined according to the methods described elsewhere (12, $25,26)$. The glucose- 6 -phosphatase and $5^{\prime}$-nucleotidase were used as markers for heavy microsomes while cytochrome $c$ oxidase was used as a mitochondrial marker. Although $5^{\prime}$ nucleotidase has been detected in the microsomal fraction (12), its presence due to contaminating plasma membranes cannot be ruled out. The ATPase activity of these fractions was determined by incubating these particles in medium containing $100 \mathrm{~mm} \mathrm{KCl}, 10 \mathrm{~mm} \mathrm{MgCl}_{2}, 4 \mathrm{~mm}$ ATP, $0.1 \mathrm{~mm}$ $\mathrm{CaCl}_{2}, 20 \mathrm{~mm}$ Tris- $\mathrm{HCl}, \mathrm{pH} 6.8$ at $37^{\circ} \mathrm{C}$. The final concentration of membrane proteins in this reaction mixture was $0.2-0.3 \mathrm{mg} / \mathrm{ml}$. The $\mathrm{Pi}$ released due to the hydrolysis of ATP was determined in the protein-free filtrate at 1,5 , and $10 \mathrm{~min}$ of incubation by the method of Fiske and SubbaRow (27). The total calcium content of these fractions were measured by Zeiss atomic absorption spectrophotometer (Carl Zeiss, Inc., New York) after extracting with $0.5 \mathrm{~N} \mathrm{HCl}$ according to the method described by Reynafarje and Lehninger (28). $\mathrm{LaCl}_{3}(1 \%)$ was added to eliminate the interference by other ions during the determination of calcium by atomic absorption spectrophotometry. ATP independent calcium binding by these fractions was determined by incubating these particles for $5 \mathrm{~min}$ at $25^{\circ} \mathrm{C}$ in a medium containing $100 \mathrm{mM} \mathrm{KCi}, 10 \mathrm{mM} \mathrm{MgCl}, 20 \mathrm{mM}$ Tris- $\mathrm{HCl}, 0.1 \mathrm{mM} \mathrm{Ca} \mathrm{Ca}^{45} \mathrm{Cl}_{2}$, and membrane protein $(0.2-0.3$ $\mathrm{mg} / \mathrm{ml}$ ).

The calcium uptake by the heavy microsomes was measured by incubating these particles (protein concentration $0.02-0.05 \mathrm{mg} / \mathrm{ml}$ ) in medium containing $100 \mathrm{mM} \mathrm{KCl}, 10 \mathrm{mM}$ $\mathrm{MgCl}_{2}, 5 \mathrm{~mm}$ potassium oxalate, $20 \mathrm{~mm}$ Tris- $\mathrm{HCl}$, $\mathrm{pH} 6.8$, $4 \mathrm{~mm} \mathrm{ATP}$, and $0.1 \mathrm{mM} \mathrm{Ca}^{45} \mathrm{Cl}_{2}$ in a total volume of $2 \mathrm{ml}$. The reaction was started by the addition of membrane protein and was stopped by Millipore filtration (Millipore Corp., Bedford, Mass.) at various times of incubation at $37^{\circ} \mathrm{C}$. The radioactivity in protein-free filtrate was estimated in Packard liquid scintillation spectrometer (Packard Instrument Co., Downers Grove, Ill.). The calcium binding by heavy microsomes was carried out at $25^{\circ} \mathrm{C}$ in the same medium as described for calcium uptake except that potassium oxalate was omitted and the protein concentration in the reaction medium was $0.2-0.3 \mathrm{mg} / \mathrm{ml}$. The incubation medium employed for estimating mitochondrial calcium uptake 
contained $100 \mathrm{~mm} \mathrm{KCl,} 20 \mathrm{~mm}$ Tris- $\mathrm{HCl}, \mathrm{pH} 6.8,4 \mathrm{~mm}$ $\mathrm{Pi}, 5 \mathrm{~mm}$ sodium succinate, $4 \mathrm{~mm}$ ATP, $10 \mathrm{~mm} \mathrm{MgCl}_{2}$, and $0.1 \mathrm{mM} \mathrm{Ca}{ }^{45} \mathrm{Cl}_{2}$ (mitochondrial protein concentration $0.2-0.3$ $\mathrm{mg} / \mathrm{ml}$ ) at $37^{\circ} \mathrm{C}$. The calcium binding by mitochondria was carried out at $25^{\circ} \mathrm{C}$ in the same medium as for mitochondrial calcium uptake except $\mathrm{Pi}$ and sodium succinate were omitted from the reaction medium and the protein concentration was $0.3-0.5 \mathrm{mg} / \mathrm{ml}$. The essential details of these methods for calcium uptake and binding by subcellular particles are described elsewhere $(12,29)$. The subcellular fractions from the hearts of control and genetically dystrophic hamsters were prepared simultaneously and were used within $2 \mathrm{hr}$ of their isolation. A uniform time between preparation of the subcellular fractions and measurement of calcium accumulation was kept in all experiments.

\section{RESULTS}

The observations reported in this paper are based on studies carried out by using both control and genetically dystrophic hamsters (BI0 14.6). As can be seen from Table I, these hamsters were of the same age (about 225 days old); however, the hearts of the dystrophic hamsters were enlarged (hypertrophic) and the heart $\mathrm{wt} /$ body wt ratio in these animals was greater than that of the control $(P<0.01)$. All these dystrophic hamsters showed varying degree of pulmonary edema, liver congestion, and generalized edema as indications of congestive heart failure. No attempt was made to assess the myocardial function in these animals since an extensive amount of information is available in this regard in the literature (20-22). We consider these animals were at the initial stages with a moderate degree of heart failure and were not at the terminal stage which is seen in these hamsters at the age of about 300 days. We have chosen to work with the genetically dystrophic
TABLE I

Heart/Body Weight Ratio and Yield of the Cardiac Subcellular Particles of Control and Genetically Dystrophic Hamsters

\begin{tabular}{lrr}
\hline & \multicolumn{1}{c}{ Control } & \multicolumn{1}{c}{ Dystrophic } \\
\hline Age, days & $230 \pm 2.5$ & \multicolumn{2}{c}{$226 \pm 5.1$} \\
Heart wt/body wt $\times 10^{3}$ & $3.87 \pm 0.5$ & $6.16 \pm 0.3$ \\
$\begin{array}{l}\text { Yield of mitochondria, } \\
\quad(m g \text { protein } / g \text { heart w } t)\end{array}$ & $1.48 \pm 0.2$ & $1.39 \pm 0.3$ \\
$\begin{array}{c}\text { Yield of heavy microsomes, } \\
(m g \text { protein } / g \text { heart w } t)\end{array}$ & $0.50 \pm 0.02$ & $0.45 \pm 0.02$ \\
\hline
\end{tabular}

The results are mean \pm SE of 6-10 experiments. The yields of subcellular fractions refer to the amounts of purified particles obtained by the method outlined in the text. The subcellular fractions were isolated by procedures " $A$ " and "B".

hamsters of this age group (about 7-8 months old) since we are interested at present to investigate the initial biochemical abnormality which may be associated with pathogenesis of heart failure.

Table I also shows that the yield of purified mitochondria and heavy microsomes isolated from the hearts of control and dystrophic hamsters was the same. These values of yields do not in any way describe the actual amounts of these subcellular particles in the control and failing hearts. It was also observed that calcium contents of the subcellular fractions obtained from the control and failing hearts were similar (Table II). Once again these values may not reflect the in vivo values but provide the required information about the preparations

TABLE II

Calcium Contents and Marker Enzyme Activities of Mitochondria and Heavy Microsomes Isolated from the Control and Failing Hearts

\begin{tabular}{|c|c|c|c|c|c|c|c|c|}
\hline \multirow[b]{3}{*}{$\begin{array}{l}\text { Calcium content, } \\
m \mu \text { moles } / m g \text { protein }\end{array}$} & \multicolumn{4}{|c|}{ Mitochondria } & \multicolumn{4}{|c|}{ Heavy microsomes } \\
\hline & \multicolumn{2}{|c|}{ Control } & \multicolumn{2}{|c|}{ Failing } & \multicolumn{2}{|c|}{ Control } & \multicolumn{2}{|c|}{ Failing } \\
\hline & 8.3 & \pm 0.2 & 8.9 & \pm 0.4 & 6.2 & \pm 0.1 & 6.1 & \pm 0.3 \\
\hline $\begin{array}{l}\text { ATP independent calcium binding, } \\
m \mu \text { moles } / m g \text { protein }\end{array}$ & 6.2 & \pm 0.3 & 6.0 & \pm 0.1 & 5.8 & \pm 0.3 & 5.2 & \pm 0.3 \\
\hline Cytochrome c oxidase activity & 1088 & \pm 70 & 1146 & \pm 54 & 120 & \pm 6 & 130 & \pm 7 \\
\hline Glucose-6-phosphatase activity & 0.13 & \pm 0.03 & 0.14 & \pm 0.02 & 1.4 & \pm 0.16 & $1.5 \varepsilon$ & \pm 0.20 \\
\hline $5^{\prime}$-Nucleotidase & 0.11 & \pm 0.01 & 0.14 & \pm 0.04 & 1.20 & \pm 0.15 & 1.60 & \pm 0.21 \\
\hline
\end{tabular}

The results are mean $\pm \mathrm{SE}$ of 4-5 experiments. Calcium contents of these fractions were determined by atomic absorption spectrophotometry while ATP independent calcium binding was observed by incubating these fractions for $5 \mathrm{~min}$ at $25^{\circ} \mathrm{C}$ in a medium containing $100 \mathrm{mM} \mathrm{KCl}, 10 \mathrm{mM} \mathrm{MgCl}$, pH $6.820 \mathrm{~m} M$ Tris- $\mathrm{HCl}, 0.1 \mathrm{~m} M$ $\mathrm{Ca}^{45} \mathrm{Cl}_{2}$, and membrane protein $(0.2-0.3 \mathrm{mg} / \mathrm{ml})$. The methods for cytochrome oxidase, glucose-6-phosphatase and $5^{\prime}$-Nucleotidase are described in the text and their activities are expressed as $\mathrm{m} \mu$ moles cytochrome oxidized/ mg protein per min, $\mu$ moles $\mathrm{Pi} / \mathrm{mg}$ protein per $\mathrm{hr}$ and $\mu$ moles $\mathrm{Pi} / \mathrm{mg}$ protein per 10 min respectively. The subcellular fractions were isolated by procedures $\mathrm{A}$ and $\mathrm{B}$. 


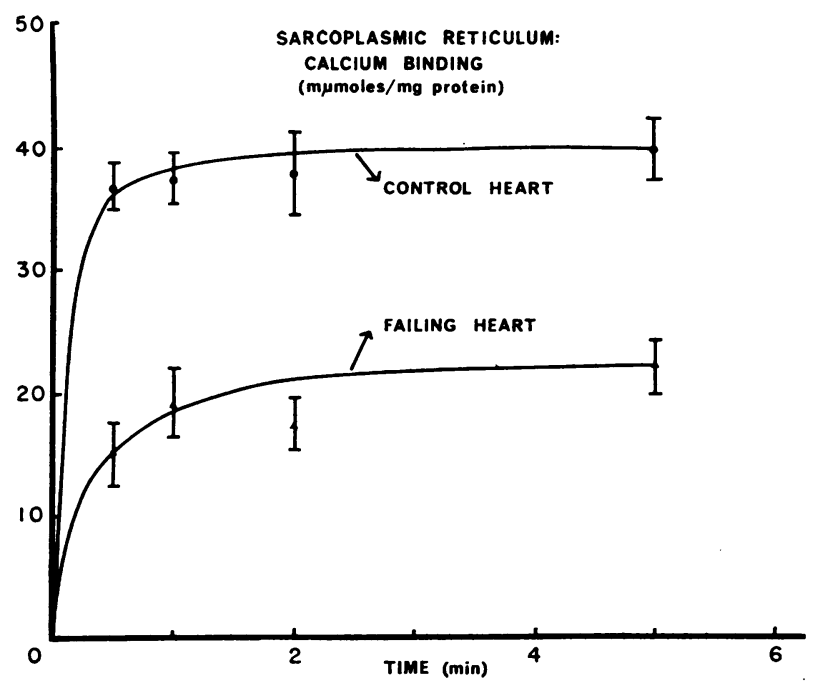

FIgURE 1 Time-course of calcium binding by the heart heavy microsomes (sarcoplasmic reticulum) on incubation in a medium containing $100 \mathrm{mM} \mathrm{KCl}, 10 \mathrm{~mm} \mathrm{MgCl}, 20 \mathrm{mM}$ Tris- $\mathrm{HCl}, \mathrm{pH} 6.8,4 \mathrm{~mm}$ ATP, and $0.1 \mathrm{~mm} \mathrm{Ca}{ }^{45} \mathrm{Cl}_{2}$ at $25^{\circ} \mathrm{C}$. The protein concentration in the reaction mixture was 0.2 $0.3 \mathrm{mg} / \mathrm{ml}$. The control hearts were obtained from normal hamsters and the failing hearts from genetically dystrophic hamsters (BI0 14.6; 7-8 months old). All values are mean ISE of five to six experiments. The calcium binding by the failing heart reticulum was significantly less than that by the control heart $(P<0.01)$. These particles were isolated by procedure $\mathrm{A}$.

employed in this study for the assessment of results obtained in vitro with these fractions. No difference $(P>$ 0.05 ) in the ATP-independent calcium binding of these fractions obtained from the control and failing hearts was noted (Table II). The activities of cytochrome $c$ oxidase, 5 '-nucleotidase and glucose-6-phosphatase in both mitochondria and heavy microsomes are also reported in $\mathrm{Ta}$ ble II. These data on marker enzymes indicate the degree of purity of the subcellular fractions.

The calcium binding (in the absence of oxalate) by heavy microsomes (procedure A) of the hearts from control and genetically dystrophic hamsters was also studied and the results are depicted in Fig. 1. Both the rate and extent of calcium binding by heavy microsomes were less in the failing heart in comparison to the control. It may be mentioned that our values for control calcium binding by hamster heart heavy microsomes are in agreement with those reported in the literature for other species $(12,30,31)$. The low calcium binding by heavy microsomes of myopathic hearts could be due to detrimental actions of lysosomal enzymes during preparation since the activities of these enzymes are considered to increase in the failing heart. Therefore acid phosphatase activity of the heavy microsomes was determined using $\beta$-glycerol phosphate as substrate by the method of
Appelmans, Wattiau, and DeDuve (32) and described by Katz, Repke, Upshaw, and Polascik (33) for these particles. The acid phosphatase activity of the control heavy microsomes was $0.1 \mu$ mole $\mathrm{Pi}$ released $/ \mathrm{mg}$ protein per $\mathrm{hr}$ at $37^{\circ} \mathrm{C}$ and was not different from that of the failing heart. Due to such low acid phosphatase activities in our fractions, it is unlikely that reduced calcium binding by the reticular fraction of the failing heart could be due to contaminating lysosomes.

Fig. 2 shows the calcium uptake (in the presence of 5 mM oxalate) by the heavy microsomes of the control and failing hearts. Although calcium uptake by sarcoplasmic reticulum (procedure $\mathrm{A}$ ) of the failing heart at $10 \mathrm{~min}$ of incubation was decreased by about $15 \%$ of the control, the values were not significantly different $(P>0.05)$ from each other. The control calcium uptake values of hamster heart microsomal fraction are within the accepted range of values for cardiac microsomes $(34,35)$. In some experiments $\mathrm{Ca}^{++}$-stimulated ATP hydrolysis was also measured. Hamster heart microsomal fraction was found to hydrolyze about $0.16-0.18 \mu$ moles of ATP/ $\mathrm{mg}$ protein per min due to the addition of $0.1 \mathrm{mM} \mathrm{CaCl}$ in the incubation medium containing $100 \mathrm{~mm} \mathrm{KCl}, 10$ $\mathrm{mm} \mathrm{MgCl}_{2}, 5 \mathrm{~mm}$ potassium oxalate, $20 \mathrm{~mm}$ Tris $-\mathrm{HCl}$, $\mathrm{pH} 6.8,4 \mathrm{~mm}$ ATP, and $0.03 \mathrm{mg} / \mathrm{ml}$ membrane protein

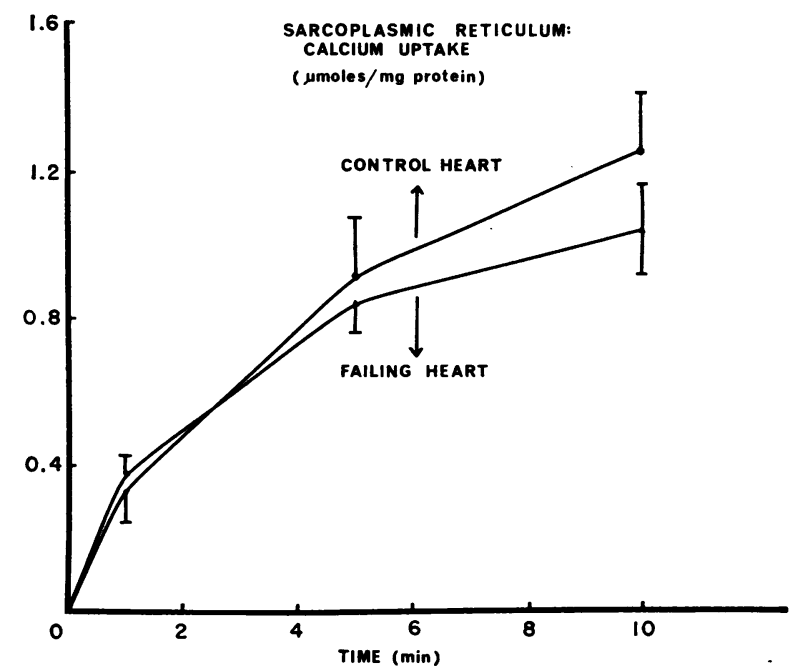

Figure 2 Time-course of calcium uptake by the heart heavy microsomes (sarcoplasmic reticulum) on incubation in a medium containing $100 \mathrm{~mm} \mathrm{KCl}, 10 \mathrm{mM} \mathrm{MgCl}, 20 \mathrm{~mm}$ Tris$\mathrm{HCl}, \mathrm{pH} 6.8,4 \mathrm{mM}$ ATP, $0.1 \mathrm{mM} \mathrm{Ca}{ }^{45} \mathrm{Cl}_{2}$, and $5 \mathrm{~mm}$ potassium oxalate at $37^{\circ} \mathrm{C}$. The protein concentration in the reaction mixture was $0.02-0.05 \mathrm{mg} / \mathrm{ml}$. The control hearts were obtained from normal hamsters and the failing hearts from genetically dystrophic hamsters (BI0 14.6; 7-8 months old). All values are mean $\pm S E$ of six experiments. The calcium uptake by the failing heart reticulum at all times of incubation was not significantly different from the control heart $(P>0.05)$. These particles were isolated by procedure A. 


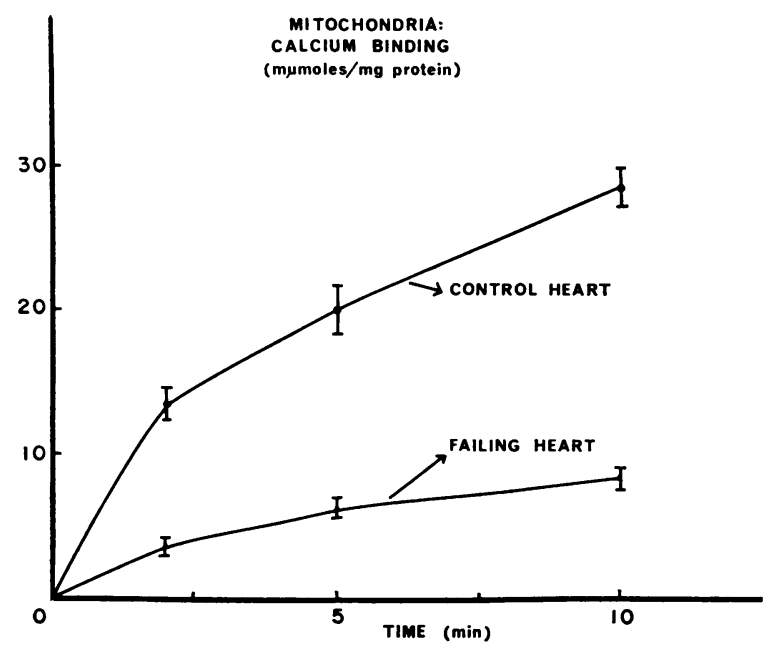

FIGURE 3 Time-course of calcium binding by the heart mitochondria on incubation in a medium containing $100 \mathrm{~mm}$ $\mathrm{KCl}, 20 \mathrm{~mm}$ Tris- $\mathrm{HCl}$, pH 6.8, $4 \mathrm{~mm}$ ATP, $10 \mathrm{~mm} \mathrm{MgCl}_{2}$, and $0.1 \mathrm{mM} \mathrm{Ca}{ }^{45} \mathrm{Cl}_{2}$ at $25^{\circ} \mathrm{C}$. The protein concentration in the reaction mixture was $0.3-0.5 \mathrm{mg} / \mathrm{ml}$. The control hearts were obtained from normal hamsters and the failing hearts from genetically dystrophic hamsters (BI0 14.6; 7-8 months old). All values are mean $\pm S E$ of four experiments. The calcium binding by the failing heart was significantly less than that by the control heart $(P<0.01)$. The mitochondria were isolated by procedure $B$.

at $37^{\circ} \mathrm{C}$. The values for $\mathrm{Ca}^{++}$-stimulated ATPase of the failing heart heavy microsomes were not different from those for the control heart.

Both calcium binding (in the absence of $\mathrm{Pi}$ and succinate) and calcium uptake (in the presence of $4 \mathrm{~mm}$ $\mathrm{Pi}$ and $5 \mathrm{~mm}$ succinate) were also studied in mitochondria obtained from the control and failing hearts (procedure B). The results described in Figs. 3 and 4 indicate a marked reduction in calcium accumulating ability of the mitochondria isolated from the hearts of dystrophic animals. The control values for calcium binding and calcium uptake by hamster heart mitochondria are within the same range as described for other species $(9,12,29)$.

In another series of experiments, calcium binding activities of the subcellular fractions isolated by procedures $\mathrm{A}$ and $\mathrm{B}$ from the control and failing hearts, were also determined in the absence or presence of oligomycin and sodium azide, the two well known inhibitors of ATP supported calcium pump of mitochondria. The results shown in Table III indicate that calcium binding by heavy microsomes was unaffected by both oligomycin and sodium azide while that of mitochondria was inhibited by $50-60 \%$ of the respective values for the control and failing hearts. Inability of azide and oligomycin to influence calcium accumulation by heavy microsomes has also been reported by other workers $(12,30,36,37)$. The subcellular fractions isolated from the control and

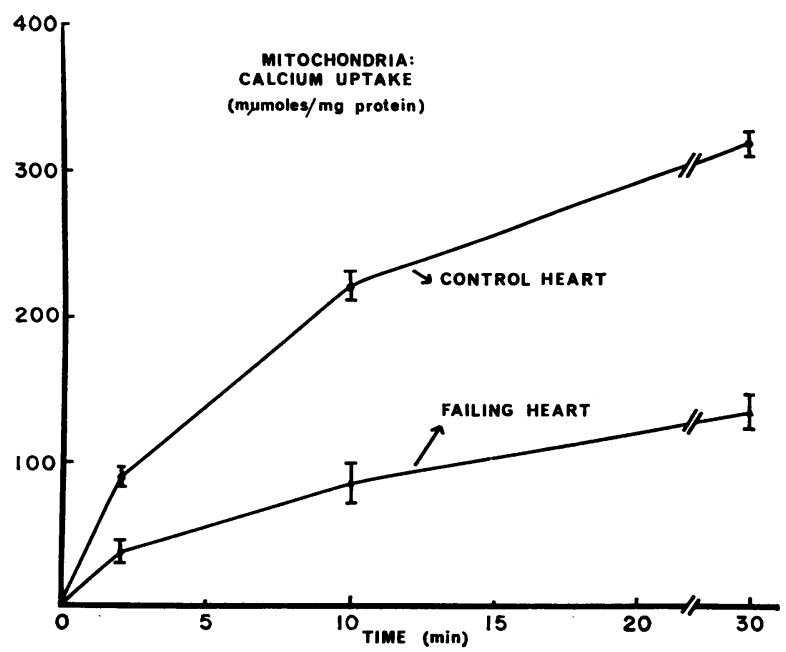

FIGURE 4 Time-course of calcium uptake by the heart mitochondria on incubation in a medium containing $100 \mathrm{~mm}$ $\mathrm{KCl}, 20 \mathrm{~mm}$ Tris-HCl, $\mathrm{pH}$ 6.8, $4 \mathrm{~mm}$ ATP, $10 \mathrm{~mm} \mathrm{MgCl}_{2}$, $0.1 \mathrm{mM} \mathrm{Ca}{ }^{45} \mathrm{Cl}_{2}, 4 \mathrm{mM} \mathrm{Pi}$, and $5 \mathrm{~mm}$ sodium succinate at $37^{\circ} \mathrm{C}$. The protein concentration in the reaction mixture was $0.2-0.3 \mathrm{mg} / \mathrm{ml}$. The control hearts were obtained from normal hamsters and the failing hearts from genetically dystrophic hamsters (BIO 14.6 ; 7-8 months old). All values are mean $\pm \mathrm{SE}$ of five experiments. The calcium uptake by the failing heart was significantly less than for the control heart $(P$ $<0.01)$. The mitochondria were isolated by procedure $B$.

failing hearts after $20 \mathrm{sec}$ of homogenization were found to bind the same amount of calcium as that observed for these hearts after $45 \mathrm{sec}$ of homogenization.

TABLE III

Influence of Oligomycin and Azide on the Calcium Binding Activities of Heavy Microsomes and Mitochondria Isolated from Control and Failing Hearts

\begin{tabular}{|c|c|c|c|c|}
\hline \multirow[b]{3}{*}{ Additions } & \multicolumn{4}{|c|}{ Calcium binding } \\
\hline & \multicolumn{2}{|c|}{ Heavy microsomes } & \multicolumn{2}{|c|}{ Mitochondria } \\
\hline & Control & Failing & Control & Failing \\
\hline & \multicolumn{4}{|c|}{$\%$ of values without inhibitors } \\
\hline & 100 & 100 & 100 & 100 \\
\hline $\begin{array}{r}\text { Oligomycin, } \\
2.5 \mu \mathrm{g} / \mathrm{ml}\end{array}$ & $93 \pm 3.6$ & $95 \pm 2.5$ & $58 \pm 4.2$ & $62 \pm 3.6$ \\
\hline $\begin{array}{l}\text { Sodium azide, } \\
\quad 5 \mathrm{mM}\end{array}$ & $98 \pm 1.2$ & $94 \pm 2.4$ & $50 \pm 3.8$ & $61 \pm 4.4$ \\
\hline
\end{tabular}

The results are mean \pm SE of three experiments. The values of calcium binding in the absence of inhibitors by heavy microsomes of the control and failing hearts were $45 \pm 2.8$ and $20 \pm 3.5 \mathrm{~m} \mu \mathrm{moles} / \mathrm{mg}$ protein respectively at $5 \mathrm{~min}$ of incubation, while these values for mitochondria of the control and failing hearts were $36 \pm 4.0$ and $11 \pm 1.2 \mathrm{~m} \mu \mathrm{moles} / \mathrm{mg}$ protein respectively at $10 \mathrm{~min}$ of incubation. Both heavy microsomes $(0.20 \mathrm{mg}$ protein $/ \mathrm{ml})$ and mitochondria $(0.25 \mathrm{mg}$ protein $/ \mathrm{ml})$ were incubated at $25^{\circ} \mathrm{C}$ in a medium containing $100 \mathrm{~mm} \mathrm{KCl}, 10 \mathrm{~mm} \mathrm{MgCl}_{2}$, $4 \mathrm{~mm} \mathrm{Na}-\mathrm{ATP}, 20 \mathrm{~mm}$ Tris- $\mathrm{HCl}, \mathrm{pH} 6.8$, and $0.1 \mathrm{mM} \mathrm{Ca}^{45} \mathrm{Cl}_{2}$. The inhibitors were added $2 \mathrm{~min}$ before starting the reaction by ATP and the reaction was terminated by millipore filtration at the times indicated above. The heavy microsomes was isolated by procedure $A$ and mitochondria by procedure B. 
TABLE IV

Influence of Oligomycin and Azide on the ATPase Activities of Heavy Microsomes and Mitochondria Isolated from Control and Failing Hearts

\begin{tabular}{|c|c|c|c|c|}
\hline \multirow[b]{2}{*}{ Additions } & \multicolumn{4}{|c|}{ ATPase activity } \\
\hline & Control & Failing & Control & Failing \\
\hline & \multicolumn{4}{|c|}{ $\mu m o l e s$ Pi released/mg protein } \\
\hline A. Heavy microsomes & \multicolumn{2}{|c|}{2 min of incubation } & \multicolumn{2}{|c|}{5 min of incubation } \\
\hline- & $4.05 \pm 0.23$ & $4.10 \pm 0.32$ & $7.62 \pm 0.65$ & $6.53 \pm 0.47$ \\
\hline Oligomycin, $2.5 \mu \mathrm{g} / \mathrm{ml}$ & $3.33 \pm 0.44$ & $3.46 \pm 0.36$ & $6.19 \pm 0.42$ & $5.82 \pm 0.39$ \\
\hline Sodium azide, $5 \mathrm{~mm}$ & $2.81 \pm 0.29$ & $2.62 \pm 0.33$ & $3.75 \pm 0.46$ & $3.25 \pm 0.26$ \\
\hline B. Mitochondria & \multicolumn{2}{|c|}{5 min of incubation } & \multicolumn{2}{|c|}{$10 \mathrm{~min}$ of incubation } \\
\hline- & $3.33 \pm 0.19$ & $3.53 \pm 0.16$ & $5.66 \pm 0.25$ & $5.25 \pm 0.33$ \\
\hline Oligomycin, $2.5 \mu \mathrm{g} / \mathrm{ml}$ & $2.18 \pm 0.24$ & $2.32 \pm 0.20$ & $3.41 \pm 0.30$ & $3.04 \pm 0.24$ \\
\hline Sodium azide $5 m M$ & $1.66 \pm 0.15$ & $1.52 \pm 0.18$ & $2.58 \pm 0.28$ & $2.72 \pm 0.31$ \\
\hline
\end{tabular}

The results are mean $\pm \mathrm{SE}$ of three experiments. The heavy microsomes and mitochondria were isolated according to the procedure $A$ and $B$ respectively. These subcellular fractions $(0.20-0.25) \mathrm{mg}$ protein $/ \mathrm{ml}$ were incubated at $25^{\circ} \mathrm{C}$ in a medium containing $100 \mathrm{mM} \mathrm{KCl}$, $10 \mathrm{~mm} \mathrm{MgCl}_{2}, 4 \mathrm{~mm} \mathrm{Na}-\mathrm{ATP}, 20 \mathrm{~mm}$ Tris- $\mathrm{HCl}, \mathrm{pH}$ 6.8, and $0.1 \mathrm{~mm} \mathrm{CaCl}$. The inhibitors were added 2 min before starting the reaction by ATP and the amount of Pi present in the protein-free filtrate was measured at the times indicated in this table.

ATPase hydrolyzing activities of microsomal and mitochondrial fractions isolated by procedures $\mathrm{A}$ and $\mathrm{B}$ respectively from the control and failing hearts, were also studied in the absence or presence of oligomycin and sodium azide. The data in Table IV show that total ATPase activities of both heavy microsomes and mitochondria of the control hearts were not different from those of the failing heart $(P>0.05)$. It may be noted that both oligomycin and sodium azide produced inhibition of total ATPase activities of the subcellular fractions. Preliminary experiments in this laboratory showed no effect of azide on the extra ATP-split by

TABLE V

Calcium Accumulation in the Absence or Presence of Oxalate by Heavy Microsomes Isolated from the Control and Failing Hearts.

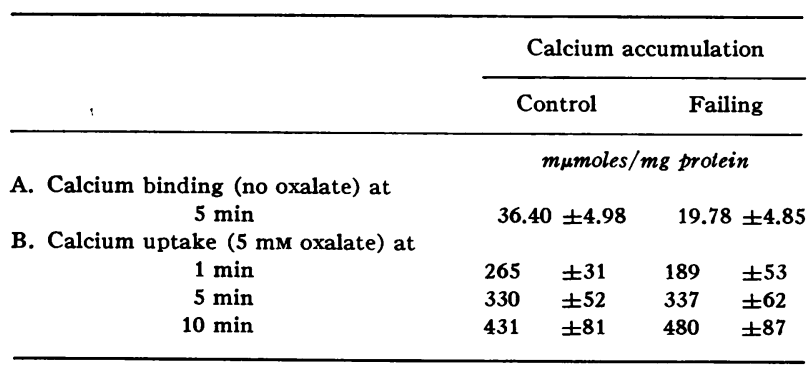

The results are mean $\pm \mathrm{SE}$ of six experiments. The subcellular particles were incubated in the medium containing $100 \mathrm{mM} \mathrm{KCl}, 10 \mathrm{mM} \mathrm{MgCl}$, $4 \mathrm{~mm}$ ATP, $0.1 \mathrm{~mm} \mathrm{CaCl}, 20 \mathrm{~mm}$ Tris- $\mathrm{HCl}, \mathrm{pH}$ 6.8. The reaction was started by the addition of subcellular particles to give a final concentration of protein $(0.2-0.3 \mathrm{mg} / \mathrm{ml})$ for binding and $0.05-0.07 \mathrm{mg} / \mathrm{ml}$ for uptake studies. These particles were isolated according to the procedure $\mathrm{C}$. reticulum due to $0.1 \mathrm{mM} \mathrm{Ca}{ }^{++}$. These observations concerning the effect of azide and oligomycin on total ATPase activity of heavy microsomes are in agreement with earlier reports $(12,30,33,36,37)$.

Since we were unable to observe significant differences between the calcium uptake (in the presence of oxalate) by heavy microsomes of the control and failing hearts, we thought to study both calcium binding and uptake by heavy microsomes isolated by a technique different than that described under procedure $A$. The microsomal fraction, isolated by the procedure $\mathrm{C}$, was equally active in terms of calcium binding but showed a lesser activity for calcium uptake than that obtained by the procedure $A$. The data reported in Table $V$

\section{TABLE VI}

ATPase Activity of Heavy Microsomes and Mitochondria Isolated from Control and Failing Hearts

\begin{tabular}{|c|c|c|c|c|}
\hline \multirow{2}{*}{$\begin{array}{l}\text { Time of } \\
\text { incubation }\end{array}$} & \multicolumn{4}{|c|}{$\begin{array}{c}\text { ATPase activity } \\
\text { ( } \mu \text { moles } \mathrm{Pi} \text { released } / \mathrm{mg} \text { protein) }\end{array}$} \\
\hline & \multicolumn{2}{|c|}{ Heavy microsomes } & \multicolumn{2}{|c|}{ Mitochondria } \\
\hline \multicolumn{5}{|l|}{$\min$} \\
\hline & Control & Failing & Control & Failing \\
\hline 1 & $3.33 \pm 0.22$ & $3.87 \pm 0.31$ & $2.94 \pm 0.44$ & $2.27 \pm 0.28$ \\
\hline 5 & $6.62 \pm 0.07$ & $5.77 \pm 0.77$ & $5.82 \pm 0.82$ & $5.63 \pm 0.32$ \\
\hline 10 & $8.93 \pm 0.43$ & $7.37 \pm 1.82$ & $8.15 \pm 0.90$ & $8.05 \pm 1.01$ \\
\hline
\end{tabular}

The results are mean $\pm S E$ of five experiments. The subcellular fractions were incubated in the medium containing $100 \mathrm{~mm} \mathrm{KCl}, 10 \mathrm{mM} \mathrm{MgCl}_{2}$, $4 \mathrm{~mm}$ ATP, $0.1 \mathrm{~mm} \mathrm{CaCl}, 20 \mathrm{~mm}$ Tris- $\mathrm{HCl}, \mathrm{pH} 6.8$ at $37^{\circ} \mathrm{C}$. The reaction was started by the addition of subcellular particles to give a final concentration of protein $(0.2-0.3 \mathrm{mg} / \mathrm{ml})$. These particles were isolated according to the procedure $\mathrm{C}$. 
reveal a decrease in calcium binding without any appreciable differences between calcium uptake by heavy microsomes of the control and failing hearts. These results clearly show a defect in calcium accumulation (in the absence of oxalate) by the cardiac heavy microsomes of genetically dystrophic hamsters. The total ATPase activity $\left(\mathrm{Ca}^{++}-\mathrm{Mg}^{++}\right.$stimulated $)$was also determined in the subcellular fractions obtained by procedure $\mathrm{C}$ from the control and failing hearts and the results are reported in Table VI. No difference in the ATPase activity of mitochondria or heavy microsomes was noted between the control and failing hearts. The high initial rate of ATP hydrolysis by the hamster heart subcellular fractions is similar to that for the rat heart reported earlier $(12,29)$.

In order to test whether the defect in calcium accumulation by mitochondria is only limited to heart, the mitochondria of liver were isolated according to the procedure $\mathrm{D}$ described in the method section. The data in Table VII shows a decrease $(P<0.01)$ in calcium binding (in the absence of $\mathrm{Pi}$ and succinate) but no difference $(P>0.05)$ in calcium uptake (in the presence of $4 \mathrm{~mm} \mathrm{Pi}$ and $5 \mathrm{~mm}$ succinate) by the liver mitochondria from the dystrophic hamsters in comparison to the control. Thus it appears that in 225-day old genetically dystrophic hamsters (BI0 14.6), heart mitochondria are more susceptible and reveal a greater degree of damage to calcium transport mechanism than liver mitochondria or heavy microsomes.

\section{DISCUSSION}

On the basis of their ability to accumulate calcium, heavy microsomes mainly and mitochondria to a certain extent are considered to regulate the concentration of free calcium in the heart $(29,30,38-40)$. If the control of intracellular calcium is important in heart function, a change in the capacity of various subcellular fractions to accumulate calcium may contribute to the pathogenesis of heart failure. The results of the present study reveal that calcium binding by both mitochondria and heavy microsomes of the failing heart from the genetically dystrophic hamster was markedly decreased in comparison to the control. This observation suggests the association of abnormal calcium pump mechanism with heart failure in these hamsters but does not in any way establish the cause-effect relation between molecular and functional events. Particularly, in the hearts of diseased hamsters of the same age group we have observed a marked decrease in creatine phosphate, ATP, ATP/ ADP (adenosine diphosphate) ratio, and ATP/AMP (adenosine monophosphate) ratio (41) which suggests an abnormality at the high energy phosphate stores. Therefore, unless an extensive study concerning the changes in the process of energy generation and utiliza-
TABLE VII

Calcium Accumulation by Liver Mitochondria Isolated from Control and Dystrophic Hamsters

\begin{tabular}{|c|c|c|}
\hline & \multicolumn{2}{|c|}{ Calcium accumulation } \\
\hline & Control & Dystrophic \\
\hline & \multicolumn{2}{|c|}{ mumoles/mg protein } \\
\hline $\begin{array}{l}\text { Calcium binding } \\
\text { (in the absence of } \mathrm{Pi} \text { and } \\
\text { succinate) }\end{array}$ & $120.87 \pm 2.85$ & $66.96 \pm 1.5$ \\
\hline $\begin{array}{l}\text { Calcium uptake } \\
\text { (in the presence of } 4 \mathrm{~mm} \\
\mathrm{Pi} \text { and } 5 \mathrm{~mm} \text { succinate) }\end{array}$ & $147.30 \pm 3.0$ & $141.37 \pm 1.0$ \\
\hline
\end{tabular}

The results are mean $\pm \mathrm{SE}$ of four experiments. The mitochondria were incubated for $5 \mathrm{~min}$ in a medium containing $100 \mathrm{~mm} \mathrm{KCl}, 20 \mathrm{~mm}$ Tris- $\mathrm{HCl}, \mathrm{pH} 6.8,10 \mathrm{~mm} \mathrm{MgCl}_{2}, 4 \mathrm{~mm}$ ATP, $0.1 \mathrm{mM} \mathrm{Ca}{ }^{45} \mathrm{Cl}_{2}$ at a protein concentration of $0.2-0.3$ $\mathrm{mg} / \mathrm{ml}$. For experiments on calcium uptake $\left(37^{\circ} \mathrm{C}\right) 4 \mathrm{mM} \mathrm{Pi}$ and $5 \mathrm{~mm}$ sodium succinate were also present in the incubation medium while these were absent when calcium binding was determined at $25^{\circ} \mathrm{C}$. The mitochondria were isolated by procedure $\mathrm{D}$.

tion as well as in calcium accumulating abilities of the subcellular fractions during the course of development of congestive heart failure is complete, the primary biochemical lesion responsible for heart failure in this disease model remains a matter of speculation.

Although ATP-dependent calcium binding by both the subcellular fractions declined markedly in the failing heart of the dystrophic hamster, no change in ATPase activity of mitochondria or heavy microsomes was noted in this study. Thus the observed decrease in calcium binding by subcellular fractions cannot be explained on the basis of changes in ATP hydrolysis. It is also unlikely that this observation can be due to the presence of inert protein contaminant in the pellet obtained from the failing heart, since both the fractions showed similar yield from the control and diseased hearts. The determination of activities of marker enzymes in these subcellular fractions also did not support this contention. It is further substantiated by our experiments in which oligomycin and sodium azide were employed during the study of calcium binding by the subcellular fractions. If the sensitivity of subcellular particles to homogenization is greater in failing heart than in the control heart, a greater loss of calcium binding may result during isolation. This possibility is unlikely since homogenization of the failing heart for $20 \mathrm{sec}$ yielded fractions having the same calcium binding capacity as of those obtained after $45 \mathrm{sec}$ of homogenization. It is however possible that such a defect in calcium binding is due to some conformational changes in the membrane which is likely to occur as a result of altered chemical composition of 
these membranes. Thus a detailed analysis of phospholipid and protein composition of the subcellular membranes of the failing heart is in progress.

We have shown in this study that calcium uptake (in the presence of oxalate) by heavy microsomes of the failing heart was not decreased significantly while calcium binding in the absence of oxalate was markedly reduced. This may mean that either the process of calcium uptake is less sensitive than that of calcium binding or this measure of calcium transport (calcium uptake) is influenced at a later stage of heart failure. It may be noted that Gertz, Stam, Bajusz, and Sonnenblick (14) have reported a reduction of ATP-dependent calcium oxalate pumping by the cardiac heavy microsomes by $22.1 \%$ in myopathic hamsters of 200 days of age and by $30-77 \%$ in animals of 300 days age. It has also been shown that in the failing rat heart perfused with substrate free medium, calcium binding by subcellular fractions decreased at the onset of failure whereas the defect in calcium uptake was delayed and was associated with the late stages of failure (12). Some investigators have suggested that calcium binding with subcellular fraction is a more physiological measure of calcium transport than calcium uptake in the presence of oxalate $(30)$. It is however significant that calcium accumulation by mitochondria in the absence or presence of $\mathrm{Pi}$ and succinate were decreased and this suggests the possibility of a greater degree of changes in the functional integrity of the mitochondrial membranes than in the microsomal particles. Defect in oxidative phosphorylation by the mitochondria from the hearts of dystrophic hamsters of the same age group as employed in this study has been reported by other workers (22) and a decrease in calcium uptake by these mitochondria has also been indicated (42). Thus it appears that calcium pump mechanism in mitochondria particularly and in heavy microsomes to a certain extent are defective in the early (initial) stages of heart failure in the myocardium of the genetically dystrophic hamsters.

\section{ACKNOWLEDGMENTS}

This work was supported by the Medical Research Council.

\section{REFERENCES}

1. Nayler, W. G. 1963. The significance of calcium ions in cardiac excitation and contraction. Amer. Heart J. 65: 404.

2. Fenton, J. C., S. Gudbjarnason, and R. J. Bing. 1966. Metabolism of the heart in failure. In Symposium on Congestive Heart Failure, American Heart Association, New York. 2nd edition. 32 .

3. Sandow, A. 1965. Excitation-contraction coupling in skeletal muscle. Pharmacol. Rev. 17: 265.

4. Edman, K. A. P. 1965. Drugs and properties of heart muscle. Annu. Rev. Pharmacol. 5: 99.
5. Briggs, F. N., E. W. Gertz, and M. L. Hess. 1966. Calcium uptake by cardiac vesicles: Inhibition by amytal and reversal by ouabain. Biochem. Z. 345: 122.

6. Katz, A. M., and H. H. Hecht. 1969. The early "pump" failure of ischemic heart. Amer. J. Med. 47: 497.

7. Gertz, E. W., M. L. Hess, R. F. Lain, and F. N. Briggs. 1967. Activity of the vesicular calcium pump in the spontaneously failing heart-lung preparation. Circ. Res. 20: 477.

8. Lee, K. S., H. Ladinsky, and J. H. Stuckey. 1967. Decreased $\mathrm{Ca}^{2+}$ uptake by sarcoplasmic reticulum after coronary artery occlusion for 60 and 90 minutes. Circ. Res. 21: 439.

9. Harigaya, S., and A. Schwartz. 1969. Rate of calcium binding and uptake in normal animal and failing human cardiac muscle. Membrane vesicles (relaxing system) and mitochondria. Circ. Res. 25: 781.

10. Suko, J., Y. Ito, J. Vogel, and C. Chidsey. 1969. Abnormal calcium uptake and ATPase in sarcoplasmic reticulum of failing hearts. Circulation. 40 (Suppl. 3) : 197. (Abstr.)

11. Dhalla, N. S., T. Rangel, and R. E. Olson. 1968. Calcium uptake and ATPase activity of sarcoplasmic reticulum and mitochondria during the course of spontaneous heart failure. Pharmacologist. 10: 208 (Abstr.).

12. Muir, J. R., N. S. Dhalla, J. M. Orteza, and R. E. Olson. 1970. Energy-linked calcium transport in subcellular fractions of the failing rat heart. Circ. Res. 26: 429.

13. Schwartz, A., L. A. Sordahl, C. A. Crow, S. Harigaya W. B. McCollum, and E. Bajusz. 1970. Several biochemical characteristics of the cardiomyopathic Syrian hamster. In 3rd Annual Meeting of the International Study Group for Research in Cardiac Metabolism. Stowe, Vt. 26. (Abstr.)

14. Gertz, E. W., A. Stam, Jr., E. Bajusz, and E. Sonnenblick. 1970. A biochemical defect in the function of the sarcoplasmic reticulum in the hereditary cardiopathy of the Syrian hamster. 3rd Annual Meeting of the International Study Group for Research in Cardiac Metabolism. Stowe, Vt. 27. (Abstr.)

15. Bajusz, E., F. Homburger, J. R. Baker, and L. H. Opie. 1966. The heart muscle in muscular dystrophy with special reference to involvement of the cardiovascular system in the hereditary myopathy of the hamster. $A n n$. N. Y. Acad. Sci. 138: 213.

16. Bajusz, E., and K. Lossnitzer. 1968. A new disease model of chronic congestive heart failure. Studies on its pathogenesis. Trans. N. Y. Acad. Sci. 30: 939.

17. Bajusz, E., J. R. Baker, C. W. Nixon, and F. Homburger. 1969. Spontaneous hereditary myocardial degeneration and congestive heart failure in a strain of Syrian hamsters. Ann. N. Y. Acad. Sci. 156: 105.

18. Bajusz, E. 1969. Dystrophic calcification of myocardium as conditioning factor in genesis of congestive heart failure. An experimental study. Amer. Heart J. 78: 202.

19. Bajusz, E. 1969. Hereditary cardiomyopathy: A new disease model. Amer. Heart. J. 77: 686.

20. Brink, A. J., and A. Lochner. 1967. Work performance of the isolated perfused beating heart in the hereditary myocardiopathy of the Syrian hamster. Circ. Res. 21: 391.

21. Brink, A. J., and A. Lochner. 1969. Contractility and tension development of the myopathic hamster (BI0 14.6) heart. Cardiovasc. Res. 3: 453. 
22. Lochner, A., A. J. Brink, and J. J. Van Der Walt. 1970. The significance of biochemical and structural changes in the development of the myocardiopathy of the Syrian hamster. J. Mol. Cell. Cardiol. 1: 47.

23. Sordahl, L. A., and A. Schwartz. 1967. Effects of dipyridamole on heart muscle mitochondria. Mol. Pharmacol. 3: 509.

24. Lowry, O. H., N. J. Rosebrough, A. L. Farr, and R. J. Randall. 1951. Protein measurement with the folin phenol reagent. J. Biol. Chem. 193: 265.

25. Nordlie, R. C., and W. J. Arion. 1966. Glucose-6-phosphatase. In Methods in Enzymology. S. P. Colowick and N. O. Kaplan, editors. Academic Press Inc., New York. 9: 619.

26. Smith, L., and P. W. Camerino. 1963. Comparison of polarographic and spectrophotometric assays for cytochrome c oxidase activity. Biochemistry. 2: 1428.

27. Fiske, C. H., and Y. Subbarow. 1925. The colorimetric determination of phosphorus. J. Biol. Chem. 66: 375.

28. Reynafarje, B., and A. L. Lehninger. 1969. High affinity and low affinity binding of $\mathrm{Ca}^{++}$by rat liver mitochondria. J. Biol. Chem. 244: 584 .

29. Dhalla, N. S. 1969. Excitation-contraction coupling in heart I. Comparison of calcium uptake by the sarcoplasmic reticulum and mitochondria of the rat heart. Arch. int. Physiol. Biochem. 77: 916.

30. Katz, A. M., and D. I. Repke. 1967. Quantitative aspects of dog cardiac microsomal calcium binding and calcium uptake. Circ. Res. 21: 153.

31. Pretorius, P. J., W. G. Pohl, C. S. Smithen, and G. Inesi. 1969. Structural and functional characterization of dog heart microsomes. Circ. Res. 25: 487.

32. Appelmans, F., R. Wattiaux, and C. DeDuve. 1955. Tissue fractionation studies. 5. The association of acid phosphatase with a special class of cytoplasmic granules in rat liver. Biochem. J. 59: 438.
33. Katz, A. M., D. I. Repke, J. E. Upshaw, and M. A. Polascik. 1970. Characterization of dog cardiac microsomes. Use of zonal centrifugation to fractionate fragmented sarcoplasmic reticulum, $\left(\mathrm{Na}^{+}+\mathrm{K}^{+}\right)$-activated ATPase and mitochondrial fragments. Biochim. Biophys. Acta. 205: 473.

34. Carsten, M. E. 1967. Cardiac sarcotubular vesicles. Effect of ions, ouabain and acetylstrophanthidin. Circ. Res. 20: 599 .

35. Katz, A. M., and D. I. Repke. 1967. Sodium and potassium sensitivity of calcium uptake and calcium binding by dog cardiac microsomes. Circ. Res. 21: 767.

36. Harigaya, S., Y. Ogawa, and H. Sugita. 1968. Calcium binding activity of microsomal fraction of rabbit red muscle. J. Biochem. (Tokyo). 63: 324.

37. Fanburg, B., and J. Gergely. 1965. Studies on adenosine triphosphate-supported calcium accumulation by cardiac subcellular particles. J. Biol. Chem. 240: 2721.

38. Fanburg, B. 1964. Calcium in the regulation of heart muscle contraction and relaxation. Fed. Proc. 23: 922.

39. Patriarca, P., and E. Carafoli. 1968. A study of the intracellular transport of calcium in rat heart. J. Cell Physiol. 72: 29.

40. Haugaard, N., E. S. Haugaard, N. H. Lee, and R. S. Horn. 1969. Possible role of mitochondria in regulation of cardiac contractility. Fed. Proc. 28: 1657.

41. Fedelesova, M., I. Toffler, J. A. Moorhouse, and N. S. Dhalla. 1970. High energy phosphate stores in cardiac and skeletal muscles of genetically dystrophic hamsters. Fed. Proc. 29: 713 (Abstr.).

42. Schwartz, A., G. E. Lindenmayer, and S. Harigaya. 1968. Respiratory control and calcium transport in heart mitochondria from the cardiomyopathic Syrian hamster. Trans. N. Y. Acad. Sci. Series II, 30: 951. 